e ISSN-0976-7223 | Visit Us - www.researchjournal.co.in

DOI : 10.15740/HAS/JJAE/7.2/365-372

\title{
Removal of tubidity from sewage water by phytorid sewage treatment plant: A study using the response surface methodology
}

\section{A.R. MHASKE, S.M. TALEY AND R.B. BINIWALE}

See end of the Paper for authors' affiliation

Correspondence to :

\section{A.R. MHASKE}

Department of Agricultural Engineering, Agricultural College, NAGPUR (M.S.) INDIA
ABSTRACT : Removal of the turbidity from the sewage water by phytorid sewage treatment plant has been studied on Agril College Maharajbag, Nagpur during the year 2012-2013. The objective of this investigation was to study the efficacy of the phytorid sewage treatment plant in turbidity removal from the sewage water and to determine the optimum condition using the response surface methodology. A BoxBehnken model has been employed as an experimental design. The effect of three independent variables namely hydraulic loading i.e. flow $\left(50-150 \mathrm{~m}^{3} \mathrm{~d}^{-1}\right)$, dilution $(10-80 \%)$ and spatial length $(16-100 \%)$ has been studied on the turbidity removal from the sewage water in bench mode of the experiment. The optimal conditions of the turbidity removal were found to be flow: $150 \mathrm{~m}^{3} \mathrm{~d}^{-1}$, dilution: 65.13 per cent and spatial length: 87.65 per cent. Under these experimental conditions, the experimental turbidity removal obtained was $7 \mathrm{mg} \mathrm{L}^{-1}$. The proposed model equation using the RSM has shown good agreement with the experimental data, with a correlation co-efficient $\left(\mathrm{R}^{2}\right)$ of 0.9743 . The result showed that optimised condition could be used for the efficient removal of the turbidity from the sewage water.

- KEY WORDS : Turbidity, Response surface methodology, Box-Behnken experimental design, Sewage water, Optimization

ם HOW TO CITE THIS PAPER : Mhaske, A.R., Taley, S.M. and Biniwale, R.B. (2014). Removal of tubidity from sewage water by phytorid sewage treatment plant : A study using the response surface methodology. Internat. J. Agric. Engg., 7(2) : 365-372. 